\title{
In the Circle of Inspiration of Anna Wierzbicka: The Cognitive Definition - 30 Years Later
}

\author{
Jerzy Bartmiński \\ Uniwersytet Marii Curie-Skłodowskiej w Lublinie \\ Pl. M. Curie-Skłodowskiej 5, 20-031 Lublin
}

\begin{abstract}
The author recalls the close ties linking Professor Anna Wierzbicka with the community of linguists centered around the journal "Etnolingwistyka"/"Etnolinguistics" published in Lublin (vols. 1-30, 1988-2018) and with Maria Curie-Skłodowska University, where in 2004 she received the title of doctor honoris causa for her research into universals in different world languages and her service as a morally sensitive humanist. The complementary character between the frameworks advocated by Wierzbicka and Lublin ethnolinguists consists in the opposition to taxonomic approaches to word meaning and the adoption of the subjective reconstruction principle, which derives from Wilhelm Humboldt's philosophy of language; in the appreciation of the role of colloquial language and the intuition of the average language user; in the use of both systemic and textual data, taking into account all relevant communication features that can be supported with "linguistic evidence"; in the use of simple sentences for definitions, which are arranged in coherent, facetted sequences. Anna Wierzbicka, similarly to Lublin ethnolinguists, postulates to capture the meaning of words in the context of social life, history and national culture. In particular, the author focuses on the concept of the so-called cognitive definition. The article discusses its genesis, construction principles and the most important inspirations for its emergence; although the concept itself was created autonomously as an extension of studies on the language of folklore, independently of Anna Wierzbicka's works, it nevertheless exhibits clear parallels to the way of thinking of the scholar from Canberra. The author of this article shows the similarities (convergences) between the cognitive definition and the NSM (Natural Semantic Metalanguage) method developed by Anna Wierzbicka on the examples of mother and gold, but it also highlights some differences, which in the case of the cognitive definition are related to the use of colloquial definientia that do not have the status of semantic "primitives" (primes). Finally, on the example of the concept HOME/HOUSE, the author considers new perspectives for applying the cognitive definition in comparative works undertaken within the framework of the EUROJOS seminar.
\end{abstract}

Keywords: cognitive definition, Lublin school of cognitive ethnolinguistics, Anna Wierzbicka, EUROJOS seminar, Leksykon aksjologiczny Stowian i ich sasiadów [Axiological Lexicon of Slavs and their Neighbours]

\section{В кругу вдохновения Анны Вежбицкой: когнитивное определение 30 лет спустя}

\author{
Ежи Бартминьски \\ Университет Марии Кюри-Склодовской \\ Pl. M. Curie-Skłodowskiej 5, 20-031 Lublin
}

Автор обсуждает тесные связи профессора Анны Вержбицкой с сообществом лингвистов, сосредоточенных вокруг журнала «Этнолингвистика», публикуемого в Люблине (тома $1-30,1988-2018)$, и Университета им. Марии Склодовской-Кюри. Здесь в 2004 году А. Вежбицкая получила звание 
doctor honoris causa за ее исследования в области универсалий на материале различных языков мира и за ее деятельность как гуманиста. Подходы А. Вежбицкой и люблинских этнолингвистов связывает противостояние таксономическим подходам к изучению смысла и принятие принципа субъективной реконструкции, вытекающего из философии языка Вильгельма Гумбольдта; в понимании значимости разговорного языка и интуиции носителя языка; в использовании как системных, так и текстовых данных с учетом всех соответствующих функциональных связей, которые могут быть поддержаны «лингвистическими данными»; в использовании простых предложений для написания толкований, расположенных в когерентных, фасетных последовательностях. А. Вежбицкая, как и люблинские этнолингвисты, отмечает, что изучать смысл слов важно в контексте общественной жизни, истории и национальной культуры. В статье автор фокусируется на концепции когнитивного определения, рассматривает ее генезис, принципы построения и наиболее важные идеи. Хотя сама концепция была создана независимо от работ А. Вежбицкой как продолжение исследований языка фольклора, между ними прослеживаются четкие параллели. Автор статьи показывает сходство между когнитивным определением и методом ЕСМ (Естественного Семантического Метаязыка), разработанным А. Вежбицкой, на примерах лексем мать и золото и также демонстрирует некоторые различия, которые в случае когнитивных определений связаны с использованием компонетов толкований, не имеющих статуса семантических примитивов. На примере концепта HOME/HOUSE автор рассматривает новые перспективы применения когнитивного определения в сопоставительных работах, проведенных в рамках семинара EUROJOS.

Ключевые слова: когнитивное определение, люблинская школа когнитивной этнолингвистики, Анна Вежбиикая, семинар EUROJOS, Аксиологический лексикон славян и их соседей

\section{INTRODUCTION}

1.1. Professor Anna Wierzbicka has special ties with linguists in Lublin. These ties have been established on both the personal (long-term friendship dating back to the times of unforgettable Prof. Maria Renata Mayenowa) and scientific level, including fruitful scientific collaboration, permanent presence of her works in university didactics at the Department of Polish Studies of Maria Curie-Skłodowska University (UMCS) and - last but not least - the development of scientific concepts in the academic circle that has recently been referred to as "Lublin Cognitive Ethnolinguistics" (LCE). Wierzbicka's articles ("Uniwersalne pojęcia ludzkie i ich konfiguracje w różnych kulturach" 1991; "Między modlitwą a przekleństwem" 1996, "O polskich słowachwartościach: dobroci, prawości i odwadze" 2011-2012) and her reviews were printed in the journal Ethnolinguistics published in Lublin; her sketch Semantyka i Ewangelia appeared in the volume $W$ zwierciadle języka i kultury (Lublin 1999); her excellent sketches on the names of animals 1993 and the split subject 2008 (concerning the situation of a bilingual person) were published in Lublin "red series", while the didacticsoriented "green series" published at UMCS reprinted six of her sketches: on the semantics of polite phrases, on dialects, jargons and styles, on the speech genres, on the semantic coherence of text, on the metatext in text, on hypotaxis and nominal constructions in the development of the Polish language. Both students and scholars read Wierzbicka's articles with pleasure, because they are well-written and address real and topical problems. Since 1998 Anna Wierzbicka has been a member of the editorial board of the journal "Ethnolinguistics". An initiative to publish in Polish her scholarly works written in Englih also originated in Lublin - the volume Język, umyst, kultura appeared in Warsaw in 1999, edited by J. Bartmiński. In 2004 Anna Wierzbicka 
received the title of doctor honoris causa at Maria Curie-Skłodowska University (see: Wierzbicka 2004). On this occasion, the UMCS publishing house published her dissertation entitled Jak można mówić o Trójcy Świętej $w$ słowach prostych $i$ uniwersalnych. The translation of Anna Wierzbicka's seminal book Semantics. Primes and Univerals (Oxford 1996) published in Lublin in 2006 unter the title Semantyka. Jednostki elementarne $i$ uniwersalne resulted in two editions of the book.

Anna Wierzbicka's works had a significant impact on shaping the profile of the journal and on the research community gathered around the journal which, embedded in the fields of ethnolinguistics or anthropological and cultural linguistics, developed its own, to some extent original, research methodology. One of the most important elements of the conceptual apparatus of LCE (encompassing such key concepts as linguistic worldview, subject, values, stereotype, point of view and perspective, profiling) is a special way of defining meanings referred to as "cognitive definition" (CD). The conception behind this definition, which will be elaborated on in detail in further sections, corresponds with the proposals made by Anna Wierzbicka (in particular those discussed in her book Lexicography and Conceptual Analysis, 1985). The cognitive definition is one of the methodological tools used in the works of Leksykon aksjologiczny Stowian $i$ ich sasiadów developed as part of the international EUROJOS seminar.

In the following I will discus (1) the genesis and development of the concept of cognitive definition; (2) its principles; (3) the most important sources of inspiration for its creation; (4) the concept development after the publication of the SLSJ pilot volume in 1980; (5) the reception of the CD conception in Poland and some misunderstandings related to its application; (6) the comparison of CD with other methods of defining (Maciej Grochowski's concept, Anna Wierzbicka's concept of NSM = Natural Semantic Metalanguage) — convergences and differences, and finally (7) new perspectives for applying CD in comparative studies undertaken within the framework of the EUROJOS seminar — on the example of the concept HOUSE/HOME.

1.2. The commentary of the editors of the book The Linguistic Worldview: Ethnolinguistics, Cognition, and Culture (see: Głaz, Danaher, Łozowski 2013) in the part devoted to the cognitive definition ${ }^{1}$, reads:

"The name of Anna Wierzbicka is especially important in the context of the so-called 'cognitive definition' of the 'mental object' associated with a given entity, of the way it is viewed, categorized, evaluated, and talked about by speakers of given languages (see Bartmiński, 1988). On the one hand, the preliminary instalment of SSSL (Bartmiński 1980) arose independently of Wierzbicka's theory of semantic primitives as a continuation of the work on folklore inspired by the linguist Maria Renata Mayenowa. However, in his major article on the cognitive definition, Bartmiński (1988) already refers to Wierzbicka's Lexicography and Conceptual Analysis (1985). This, in the words of the former author (p.c.), is Wierzbicka's most interesting work, with an introduction that contains an excellent

1 „The cognitive definition”, pp. 137-224; it featured articles by Anna Wierzbicka, Jerzy Bartmiński, Katarzyna Prorok and Adam Głaz, Stanisława Niebrzegowska-Bartmińska and Agata Bielak. 
account of a comprehensive semantic description that is also pursued by the Lublin-based ethnolinguists.

It therefore seemed justifiable to include Anna Wierzbicka's chapter at the beginning of the section on the cognitive definition in this volume: her explications have conceptually fuelled the pursuits of Bartmiński and his collaborators and while the two approaches arose independently, they follow the same general path" (Głaz, Danaher, Łozowski 2013: 16).

Comparing the assumptions of LCE with her own concept of NSM, Anna Wierzbicka wrote herself:

"Despite the fact that we work in different fields, from different viewpoints, in different disciplinary contexts, and with different methodologies, I consider our approaches to be complementary and the directions of our research to be convergent" (Wierzbicka 2013: 137).

The complementary nature of NSM and LCE can be attributed to the fact that, among others, both stand in opposition to traditional taxonomic interpretations of lexical meaning and adopt the principle of reconstructing the meaning by the speaking subject, which in turn is derived from the philosophy of language postulated by W. Humboldt.

"The main objective of the cognitive definition is to reflect the way of understanding a given object by speakers of a particular language, i.e. on the basis of the socially accepted and language-mediated knowledge of the world, categorisation of linguistic phenomena, their characteristics and axiology" (Bartmiński 1988: 169).

Likewise, Anna Wierzbicka bases her definitions (explications) on the intuition of a language user (Wierzbicka 1993: 262-264). Both conceptions converge in that their explications go beyond the taxonomic features (necessary and sufficient to separate the object) and take into account all semantically relevant characteristics. Both refer to lexical, phraseological, paremiological and textual sources, including stereotyped texts. Both build definitions using simple sentences linked together into coherent sequences that are grouped according to facets.

\section{THE ORIGIN AND DEVELOPMENT OF THE CD}

The conception of a new linguistic definition that for some time has been referred to as the cognitive definition, was born over thirty years ago and has its own "little story".

2.1. It was used for the first time in the pilot issue of Stownik ludowych stereotypów jezzykowych [Dictionary of folk linguistic stereotypes] (SLSJ 1980) as an alternative to minimalist definitions (postulated by M. Grochowski, 1975, 1993) and taxonomic, scientistic definitions practiced widely in the Polish lexicography ${ }^{2}$. In 1980, the author of the introduction to SLSJ commented on the assumptions of the definition in the following words:

"The content of the definition always corresponds to some knowledge of the world. Upon defining the sun as 'a central celestial body of the solar system, a ball of gas with

${ }^{2}$ Renata Przybylska recognised the CD to be equivalent to the types of definitions discussed by Witold Doroszewski in the introduction to SJP [Dictionary of the Polish Language, vol. 1, 1958: $\mathrm{XXX}-\mathrm{XXXV]}$ : realistically semantic, structurally semantic, structural, extensional, synonymic and grammatical (Przybylska 2003: 229). However, in fact, due to its subjectivity (how people understand the words, not what words mean) the CD stands in opposition to all of them. 
very high temperature, radiating vast amounts of energy [...]' (sun defined in an academic dictionary) we would be in line with the requirements of logic regarding building real equivalent definitions, but we would perform a jump into another consciousness, another worldview, another culture. In [our] dictionary we want to avoid such explications that would subsume folk ideas about the world under the concepts adopted in the literary language. [...] For the representative of the folk culture the sun is rather 'the brightest light in the sky that illuminates and warms the Earth, it is the cause of life on Earth, and by moving itself determines the measure of time"" (SLSJ 1980: 23-24).

In the pilot issue of SLSJ 1980, apart from the definition of the concept sun, other similar definitions were constructed for, inter alia, stars, cuckoo, horse and ox or even thaler and rosemary. Consider, for example, the following definitions ${ }^{3}$ :

Star - "a little light in the sky shining at night. Its behaviour and location may be used to tell one's fortune. Everyone has their own star - destiny"4.

(Cf. definition in USJP 2003: "a celestial body composed of gases and plasma, emitting light as a result of thermonuclear reactions taking place in its interior...")

Cuckoo - "a grey or white bird that cuckoos in the woods, near the house, it lays its eggs in the nests of other birds and does not care about their fate; according to folk beliefs its voice foretells luck (long life, wedding, spring, children, money) or misfortune (death, spinsterhood, illness, hunger, bad weather). Associated with single women and sorrow, tears"s.

Horse - "livestock animal; big, strong, valuable; wise, faithful; helps people, can sense the death of a man; used for riding and in teams (i.e. for driving a car or to plough and harrow), most appreciated among farm animals, considered the animal of a man (host, bachelor, soldier) while the female animal was a cow. Having a horse was a sign of wealth and the source of pride. Qualities attributed to horse: spontaneity and demonic" $"$.

The source of the definitions included in the pilot issue were dialectological (dictionaries, atlases, text records) and ethnographic data (records of beliefs and practices), and in particular stereotyped texts (examples of collective oral creativity: songs and poems, riddles and proverbs, fables and stories). Etymological dictionaries were reported to be particularly useful, because finding the onomasiological base of a name provides information relevant to arriving at the linguistic conceptualization of a given entry (Bartmiński 2013c). Existing data were continuously supplemented with data obtained in the course of interviews with field informants, which over time have been expanded by using systematic surveys.

2.2. In hindsight, the trial issue of SLSJ 1980 can be considered a "manifesto" of the Lublin Cognitive Ethnolinguistics as it included all the most important ideas developed further by the Lublin-based team of linguists in their works. This does not mean, however, that the new proposal for defining concepts in a cultural context was not modified in subsequent years and developed further. On the contrary, it was taking its final shape gradually as more studies were published by the author and his associates.

${ }^{3}$ I cite definitions in a condensed form, full definitions are much longer as they encompass explication and textual documentation.

4 SLSJ 1980: 74-79; entry prepared by Jadwiga Chodukiewicz.

5 SLSJ 1980: 145 - 158; entry prepared by Irena and Czesław Kosylowie.

${ }^{6}$ SLSJ 1980: 119—144; entry prepared by Jerzy Bartmiński. 
In the years 1988-1996 the members of the ethnolinguistic team tested the CD on selected examples such as stars (Niebrzegowska 1990), and korovai, crying, nightmare, roadside, strzygon', sea, new moon ${ }^{7}$. This period of testing the applicability of the $\mathrm{CD}$ ended with the new edition of the entry sun $^{8}$. While respecting all the requirements formulated earlier, the documentation was divided according to speech genres and this innovation proved to be very fruitful as it opened up interesting research perspectives for the study of text genres in folklore, it also allows to extract the semantic specificity of proverbs, riddles, folk healer orders and other genres. The entry sun became a model for the development of all entries in the first volume of Stownik ludowych stereotypów i symboli ludowych (SSiSL) [Dictionary of Folk Stereotypes and Symbols], which has been published since $1996^{9}$.

The conception of the CD in a more or less "orthodox" form was also used for subsequent entries coming from both the folk Polish — Danube, rock, ash — and the standard language - mother, equality, responsibility, text ${ }^{10}$.

2.3. The rules of this type of defining can be generally and synthetically presented below:

(1) The definition answers the question of how people understand the words (subjectively) and not what is the meaning of lexical items (objectively); in other words, the proposed definition refers to the epistemology, it reflects the consciousness of language users, and not - as in the case of "academic" definitions (e.g. SJP Dor) the "objectivist" realm, i.e. answers to the question "what does the word mean and which object does it refers to?".

(2) The definition (also referred to as explication) reflects in definientia common knowledge about the world as well as widely-held beliefs and axiology, in short the common conceptualization of the world; therefore, the meta-language of description is colloquial Polish while scientific language is avoided.

(3) The subject of the definition is a "mental object"; however, the definition is not limited to listing only its "necessary and sufficient" features (for taxonomic purposes), but includes a whole array of characteristics, entrenched in the linguistic worldview of this object.

(4) In contrast to differentiating the meaning with the use of abstract semantic markers ("semes"), the main component of the $\mathrm{CD}$ is a stereotypical (conventionalised) evaluation of a prototypical entry (concept) in the linguistic form of a sentence or text.

(5) Definitions are subjected to parametrization (this was already done in the pilot issue of 1980); subcategories are singled out and called "facets": they refer to the name and its position in the language system: hypernym, hyponym, cohyponyms, synonyms and oppositions, metaphoric and symbolic uses of the entry and its cultural equivalents; but parameterization includes also such characteristics of the entry as collections, origin, parts, attributes, quantification, subject roles (agent, stator, processor, sensor), object

${ }^{7}$ For further information, see Maksymiuk-Pacek and Niebrzegowska-Bartmińska 2009.

8 Bartmiński, Niebrzegowska 1994.

9 See SSiSL 1996-2017.

${ }^{10}$ For further information, see Maksymiuk-Pacek and Niebrzegowska-Bartmińska 2009. 
roles (object, instrument, recipient, locator, material for making something). The selection and arrangement of facets should reflect the way the cognitive content entrenched in language is structured.

(6) Due to the significant extension of the definition the sample material (documentation) is presented in a separate text block, separated from the explication. During the development of the entry sun (Bartmiński, Niebrzegowska 1994) the division of the documentation into distinct types of context was introduced for the first time.

\section{SOURCES OF INSPIRATION}

The concept of the CD has a substantial historical and theoretical basis.

3.1. The fact that the CD is based on the speaker's knowledge, on the awareness of an average language user rather than on scientific knowledge, refers to the tradition of anthropological linguistics, in particular German tradition, i.e. the cultural and linguistic approach postulated by Johann Herder (language is the treasury of the thought of an entire people) and Wilhelm Humboldt (2001/1836) (each natural language carries a certain vision of the world, worldview, Weltanschauung, and a way of perceiving the world, Weltansicht, and the character and structure of a language expresses the inner life and knowledge of its speakers), the philosophical tradition of Immanuel Kant (objects of experience are mind-dependent) and Ernst Cassirer (cognition is a symbolic assimilation of phenomena by the human mind, and culture is a world of symbolic forms), as well as the British linguistic anthropology in the spirit of Bronisław Malinowski (1987/1935) (to perceive the world through the eyes of a native and respect his canon of behaviour). The understanding of stereotype adopted by the LCE owes much to Walter Lippmann (1922) and Hilary Putnam (1975). The latter tasked linguists with developing methods of describing a stereotype; the $\mathrm{CD}$ is an attempt to undertake this task.

3.2. The postulate to build a definition by grouping sentential contexts that communicate stereotypical judgments about the subject and show the lemma in various combinations, corresponds to the concept of the contextual definitions, axiomatic definitions or definition by postulates (Ajdukiewicz 1965: 79-82), and partial definitions, whose rules in Polish were introduced by Pawłowski (1978) in reference to the works by Rudolf Carnap and Ludwig Wittgenstein. In particular, the concept of the CD owes much to the inspirations coming from semiotics (Ivanov and Toporov 1965), semantics (Wierzbicka 1971, 1984, 1985), ethnolinguistics (Tolstye 1978) and works by Apresjan (1982/1974).

3.3. The principle of combining definitional sentences into semantic subcategories is based on the categorization used in syntax, modern word-formation, and semantics ${ }^{11}$ and it refers to the Aristotelian tradition. The categories of substance, size, quality, relation, place, time, status, activities etc. distinguished by Stagirite were the result of "the observation of the attitude of a mere mortal towards the surrounding world" 12 .

11 See: Klemensiewicz 1958, Fillmore 1971, Dokulil 1979, Grzegorczykowa 1984.

12 Jodłowski 1971: 14. 


\section{THE DEVELOPMENT OF THE CONCEPT OF THE CD AFTER THE PUBLICATION OF THE PILOT ISSUE OF SLSJ (1980)}

After the publication of the pilot issue in 1980 the work on the CD was continued. In 1984, in the article entitled Definicja leksykograficzna a opis języka [Lexicographic definition and the description of language] (Bartmiński1984) scientistic ("taxonomic") definitions were criticized and justification was given to the demand for going beyond the necessary and sufficient features in the direction of the connotative features ${ }^{13}$.

In the article from 1988 entitled Definicja kognitywna jako narzedzie opisu konotacji [The cognitive definition as a tool for describing connotations] the term "cognitive definition" was introduced, its use was justified and four basic principles of the CD were formulated: content adequacy, structural adequacy, reference to a typical (stereotypical, prototypical) object, facet parametrization (Bartmiński 1988).

The CD was introduced as the primary way to draw up articles in Stownik stereotypów i symboli ludowych [Dictionary of Folk Stereotypes and Symbols], published in Lublin since 1996; 5 issues have been published so far (see SSiSL 1996-2017).

Subsequent articles discussed the open nature of the CD (Bartmiński, Tokarski 1993) and the importance of the operation of profiling the underlying ideas (Bartmiński, Niebrzegowska 1998; Bartmiński, Chlebda 2013c). The CD was characterised as a text of culture (within the meaning of the Tartu school, Bartmiński 2013a) and narrative text (Bartmiński 2014a), the significant role of etymological data was shown (Bartmiński 2013c) and the usefulness of surveys in creating the CD was emphasized (Bartmiński 2014b). Two possible perspectives (semasiologic and onomasiatic) were distinguished in the creation of the $\mathrm{CD}$ and reconstruction of the linguistic worldview (Bartmiński 2015).

\section{THE RECEPTION OF THE CD IN THE COMMUNITY OF POLISH LINGUISTS}

The concept of the CD met with favourable response on the part of the scientific community in Poland, which can be measured by the publication of a series of articles written according to the proposed design / idea and the spread of the term "cognitive definition". The search word "cognitive definition" yields over two thousands entries on Google.

The translations into foreign languages of the article about the CD from 1988 (in Russian, English, Serbian and Czech) is a clear sign of interest on the part of foreign scientists.

5.1. Although the definition was created for the explication of folk stereotypes, it was recognized relatively quickly (and correctly) that it also applies to the nationwide vocabulary and is not limited only to popular varieties of the language. The first work

${ }^{13}$ Piotr Żmigrodzki recognized that "[this] text initiated certain movement in the Polish metalexycographic discussion" and that "only in 2000 Inny stownik języka polskiego was published, which introduced definitions which - in broad outline - met [...] Bartmiński's postulates, and which definitely broke off with scientism so prevalent in the Polish lexicography in the past" (Żmigrodzki 2010: 33-34). 
written by an author outside of the Lublin centre but modelled on the articles published in SLSJ 1980 was an article by Janusz Anusiewicz, who developed the CD of $c a t^{14}$ and horse $e^{15}$. A number of articles with the phrase "cognitive definition" in the title were published. The CD was used to describe both common - democracy ${ }^{16}$, tabloid $^{17}$, number seven $^{18}$ - and proper names, among others mythological concepts: Marzanna ${ }^{19}$, Perun $^{20}$, Wotos $^{21}$. There have also been some books published, which may not feature the term CD in the title, but their authors explicitly declare the application of its principles. For example, S. Niebrzegowska-Bartmińska in her dissertation Wzorce tekstów ustnych $w$ perspektywie etnolingwistycznej (2007) [Patterns of oral texts: An ethnolinguistic approach] devoted a chapter to the "cognitive definition of a text" (pp. 23-28). Katarzyna Smyk described Christmas tree ${ }^{22}$, Szymon Pawlas — God/gods ${ }^{23}$ and Michał Grech - university ${ }^{24}$.

5.2. Not all attempts to use the CD are equally successful. This leads sometimes to confusion when it comes to how it is understood and applied.

It is a mistake to bring the essence of the CD to the facet system of definitional sentences. This feature is important (because it helps to understand the processes underlying the profiling of a concept in different discourses), but by no means the most important - in an article from 1988 it is listed as the last, fourth one. The most important is content and structural adequacy in relation to language user's awareness.

The second misunderstanding is connected with the way the survey results are used. The answers given by respondents are not and cannot be regarded as ready definientia ${ }^{25}$, they require generalising reinterpretation. Besides, not all object features listed by the respondents in the questionnaire are worthy of their inclusion in the definition. Meaning has a concentric structure: it is composed of the nuclear features (mentioned in the questionnaire regularly and often), and peripheral features (mentioned rarely, often only once).

Debatable is also the issue of openness of the CD. The semantic definition differs from the encyclopaedic one in this respect that the former exposes these features for which we can provide hard "linguistic evidence" (a term used by Wierzbicka 1993: 259) or which we can submit to certification (Bartmiński 2015). The openness was ascribed to the CD in the article Definicja semantyczna: czego i dla kogo (Bartmiński, Tokarski 1993), because apart from explicit characteristics there are consecutive characteristics accessible as "cognitive paths"; the openness of definitional characteristics is indicated

\footnotetext{
4 Anusiewicz 1989, 1994: 117-139.

5 Anusiewicz 1994: 139-149.

6 Grzeszczak 2009.

7 Skowronek 2010.

8 Wójtowicz 2013.

9 Łuczyński 2008.

20 Łuczyński 2011.

21 Łuczyński 2012.

Smyk 2009.

3 Pawlas 2013.

4 Grech 2013.

25 See: Jedliński 2000.
} 
clearly by the results of the survey, which show that the characteristics attributed to a given object by the respondents arranged according to the frequency of their appearance show a system that expires gently without clear thresholds (Bartmiński 2014b). It cannot be forgotten, however, that definitional features are characterised by a different degree of entrenchment, and the most significant aspects of the entrenchment of those features are: names (their "internal form" revealed in the etymological and word-formation analysis), derivatives, collocations, metaphorical uses, their use in presuppositions and predicatives. I will show this in more detail on the example of gold (see below).

\section{THE CD VIS-À-VIS MACIEJ GROCHOWSKI'S MINIMALIST (STRUCTURAL) DEFINITIONS AND ANNA WIERZBICKA'S NATURAL SEMANTIC METALANGUAGE (NSM)}

6.1. The Lublin Cognitive Ethnolinguistics stands in opposition to the minimalist, structuralist definitions of Maciej Grochowski $(1975,1993)$, but at the same time is close to Anna Wierzbicka's cultural semantics. I will elaborate on this only briefly. Maciej Grochowski 1993) postulated defining the meaning by using only a minimalist set of features understood as strictly structural criteria:

A cabinet is a thing that has been made so that people could store their other things in it.

A stool is the thing that has been made so that people could sit on it.

$A$ bed is a thing that has been made so that people could lie on it. Etc.

The definition consists of an overarching category and a differentiating feature. Grochowski opts for minimalist definitions which contain only the semantic core of words including only the features that are most entrenched, necessary and sufficient. In this proposal, there is no room for linguistic or cultural connotations. I pointed out the weaknesses of this type of definition in the article Definicja leksykograficzna a opis języka (1984), where I stressed that it does not reflect what is entrenched in natural language and what constitutes the relevant component of linguistic communication.

6.2. Unlike Grochowski, Anna Wierzbicka (similarly to LCE) calls for capturing the meaning of words in the context of culture. Both the CD and Wierzbicka's concept have similar orientation. Although the idea of the $\mathrm{CD}$ was born independently, already in 1980, it was only after the publication of the book by Anna Wierzbicka Lexicography and Conceptual Analysis (1985) in which defining features were subjected to precise structuring and grouped into facets, that the concept of the $\mathrm{CD}$ has been enriched with the notion of facet and a particular order of the facets that reflects the cognitive structure of concepts was established.

6.3. Nonetheless, there are also some differences.

Although both Anna Wierzbicka and LCE assume the principle of simplistic analysis (rendering complex concepts by simpler ones), Wierzbicka in her explications uses elementary semantic components whose number is very limited, while LCE operates with much richer repertoire of defining expressions derived from the popular vocabulary (used as the metalanguage of semantic description), which correspond, to some degree, to "semantic molecules" in Wierzbicka's theory. Consider, for example, the definitions of mother. 
In addition to strictly linguistic data, the $\mathrm{CD}$ also refers to 'paralinguistic' data, practices and beliefs; explications of lexical items belonging to standard national language also use experimental data (survey results). It also takes into account the basic content of lexemes and asks how this content is profiled in discourse.

6.4. Mother as explained by Anna Wierzbicka and by LCE. The explanation of mother by Anna Wierzbicka.

Wierzbicka's defnition of a mother couched within her Natural Semantic Metalanguage contains the biological, sociological and psychological components of the concept:

$X$ is Y's mother. $=$

(a) at one time, before now, $Y$ was very small

(b) at that time, $Y$ was inside $X$

(c) at that time, $\mathrm{Y}$ was like a part of $\mathrm{X}$

(d) because of this, people can think something like this about $X$ :

' $\mathrm{X}$ wants to do good things for $\mathrm{Y}$

$\mathrm{X}$ doesn't want bad things to happen to Y' (Wierzbicka 2006b: 186-187).

Matka according to LCE (cf. Bartmiński, ACE 2009, pp. 146-147):

The following aspects (facets) can be recognized in the characterization of the mother: biological, psychological, social (relation to other people), ethical and connected with everyday life. A facet-based arrangement of the features reveals a greater importance of the social aspect relative to others (cf. again the proverb "the mother is not she who has given birth, but she who has raised'):

The superordinate category:

[1] 'is a female'

biological aspect:

[2] 'has a child' [= gives birth $]$

[3] 'breastfeeds'

[4] 'transmits her features to the child' social aspect:

[5] 'looks after'

[6] 'assists'

[7] 'provides shelter'

[8] 'occupies an important position in a group'

(8a) 'occupies the most important position'

[9] 'punishes and beats her children'

[10] 'gives advice to the children'

[11] 'teaches her daughter how to work'

[12] 'children (should) obey the mother'

[13] 'the child should be grateful to the mother for her care'

socio-psychological aspect:

[14] 'is tender and loving'

[15] 'good' ( $\leftarrow$ 'looks after', 'is tender and loving', 'provides shelter')

[16] 'accepts one unconditionally'

[17] 'is treated with fondness and tenderness'

[18] 'one loves one's mother' 
aspect of everyday life (behavior):

[19] 'manages the home'

[20] 'gives orders, drives one to work, scolds, beats'

[21] 'is busy'

[22] 'is the only one and irreplaceable for the children'

[23] 'will recognize her child in any situation'

[24] 'marries her daughter'

psychological aspect:

[25] 'is emotional' ( $\leftarrow$ 'tender and loving')

[26] 'is understanding'

[27] 'is wise'

[28] 'is strict (her instrument is a stick)'

ethical aspect:

[29] 'sets an example to follow'

[30] 'is dedicated'

[31] 'is self-sacrificing, disinterested'.

The selection of aspects and specific characteristics is decisive for the profiling of the linguocultural image of the mother in social discourse. The different profiles are constructed from the points of view of different speaking subjects: a child, an adult, the family, a local community, the Church. All profiles, nevertheless, are anchored in the base set of features, which I have attempted to reconstruct on the basis of a variety of sources: the language system, texts and questionnaires.

6.5. The principle of certification of features included in the CD: the example of gold. If we put forward the postulate that the definition should bring us closer to the linguistic picture of an object, or should even recreate it, we should adopt the principle of certification of all features considered to be defining and show "linguistic evidence". The authors of dictionaries usually do not comply with this principle (with the possible exception for ISJP ed. by Bańko). The principle was clearly formulated by Anna Wierzbicka in her book Lexicography and Conceptual Analysis (1985) and in the article Nazwy zwierzat [The names of animals] (1993). Since "the main objective of the cognitive definition is to reflect the way of understanding a given object by speakers of a particular language, i.e. on the basis of the socially accepted and languagemediated knowledge of the world, categorisation of linguistic phenomena, their characteristics and axiology" (Bartmiński 1988:169-170), the quantity and quality of features given in such a definition must be subject to the certification procedure, it cannot be treated arbitrarily. Popular knowledge in contrast to scientific knowledge can be encapsulated in a certain circle of socially conventionalised and stereotypical judgments about the object. Such features may be objectively verified, because they reflect the collective awareness and knowledge ${ }^{26}$.

${ }^{26}$ It should be added that as opposed to these, encyclopaedic definitions (recognised as scientific ones) are not (by their very nature) accepted by the society (although they could), are created on the basis of specialist knowledge developed continuously, they also depend on the competences of the author of an article and in this sense are "subjective". This paradox was stressed by Anna Wierzbicka (1993: 252-253). 
"Linguistic evidence" encompasses secondary and figurative meaning of a lexical item, its etymology, meaning entrenched in derivates and present in fixed collocations and phraseological units, as well as the characteristics communicated by stereotyped texts (e.g. proverbs) and presupposed in individual texts.

In light of these criteria the definition of gold can involve the following features:

- 'being a metal' - due to contextual embeddedness: gold, silver, copper and other metals;

- 'precious, valuable' - due to phraseological units: sb/sth is like gold 'sth/sb very precious'; $\mathrm{sb} / \mathrm{sth}$ is worth its weigt in gold 'sth/sb respected and valuable'; black gold 'coal'; white gold 'cotton'; gold medal 'the best prize'; proverb: Speech is silver, silence is gold;

- 'with very positive axiology, since we speak e.g. gold-tongued 'a talented speaker'; and emotional approval: cf. phras. gold, not human 'of a man with very positive character traits'; my gold one, 'a tender address to the loved one or a close person';

- indicating 'richness', phras. a vein of gold, gold business, gold mine 'sth that brings high profits'; and derivates such as gold-bringing 'generating high profits'; promise sb mountains of gold 'promise big wealth';

- 'of yellow colour' - cf. derivates: golden 'gold-like colour, shining like gold'; ztocień [chrysanthemum] 'plant with goldish yellow flowers'; numerous lexical blends or compounds with gold- being the first part of the word: gold-haired, gold-feathered, gold-coloured, etc.;

- 'shimmering / shiny' — cf. to gold 'shimmer like gold'; proverb: All that glitters is not gold;

- 'used to produce jewellery', the secondary meaning of gold is 'products made of gold'; cf. also derivates: goldsmith, goldsmithery, to gild;

- 'sth desirable, object of desire', cf. phras. gold rush.

The shortest cognitive definition of gold in Polish should be something like: 'precious metal, most valued, of yellow colour, highly shiny, a sign of wealth, subject of admiration and lust, used for making decorative and symbolic objects (such as wedding rings, liturgical vessels, coins, etc. $)^{27}$.

Among the features mentioned there are those entrenched more strongly ('yellow colour') or less ('shiny'), some ('a sign of wealth') are derivable from the other ('precious'). There are features that are "denotative", "encyclopaedic", characteristic of the object itself ('yellow', 'shiny', 'used to make jewellery'), and "connotative", resulting from the subjective perception ('precious', 'a sign of wealth' and 'object of desire'); the boundary between the "denotative" and "connotative" features is blurred, fuzzy (cognitive scientists question its significance). At the same time, a set of features attributed to the object is open.

${ }^{27}$ Similar procedure in building definitions was used by the authors of the entry horse (Bartmiński in SLSJ 1980), cat (Anusiewicz 1990, 1995), sun (Bartmiński, Niebrzegowska 1994), stork (Bartmiński, Niebrzegowska-Bartmińska 2008), text (Niebrzegowska-Bartmińska 2007); it is used by the authors of entries in SSiSL 1996-2017. 
This highly interpretive nature of the popular perception of gold was presented recently in SSiSL (Bartmiński, Prorok, 2012). It is based on systemic data and records of different genres of texts (including poetry); it encompasses all, also contextual, connotations of gold. This is a picture more complex than that in the standard Polish language, different to a large extent, created from the point of view and perspective of a "simple" and poor man, for whom gold is an unattainable good of somewhat mythical value.

\section{THE APPLICATION OF THE CD IN COMPARATIVE STUDIES UNDERTAKEN WITHIN THE EUROJOS SEMINAR}

The concept of the CD was - as already mentioned — used on a large scale in $\mathrm{SSiSL}^{28}$. The experience gained while developing this dictionary and the concepts developed within the Polish cognitive ethnolinguistics ${ }^{29}$ became the point of departure and offer for the associates of the EUROJOS programme who undertake comparative semantic studies on the international scale.

The premise of the EUROJOS programme, affiliated since 2009 with the Institute of Slavic Studies of the Polish Academy of Sciences (and since 2015 also with the Ethnolinguistic Commission of International Committee of Slavists) is to develop parallel descriptions of important cultural concepts in different languages (Slavic and others). In order for such descriptions to be comparable, they must rely on a comparable set of sources and operate with similar definitions. The CD is a proposal which can help meet these criteria.

At the first stage, the analyses of the 5 concepts have been prepared: HOME/ HOUSE, EUROPE, WORK, FREEDOM and HONOUR. In 2015-2018 the first four volumes were published (HOUSE/HOME, WORK, HONOUR and EUROPE).

The first volume of Leksykon aksjologiczny Stowian i ich sasiadów [Lexicon of the Axiology of Slavs and their Neighbours] devoted to HOUSE/HOME gathered parallel description of this concept in 18 languages $^{30}$.

The descriptions of the concept HOUSE/HOME in different languages were compiled according to a single, agreed model. Following a general introduction and presentation of the state of research, it presents:

- systemic data $(\mathrm{S})$ : dictionary definitions of house/home names; hypernyms, synonyms; oppositions; derivates; collections and complexes; loose collocations and fixed phrasemes; metaphors;

- survey data (A), answers to the question: "What according to you is the essence of a true home/house?"; respondents: a group of 100 students;

- textual data $(\mathrm{T})$, derived primarily (but not exclusively) from the high-circulation press and national language corpora.

28 See SSiSL $1996-2017$.

29 See Nepop-Ajdaczyć 2007; Zinken 2009; Głaz, Danaher, Łozowski (eds.) 2013.

30 This included the following languages: Polish and Czech, Russian, Belarusian and the microlanguage Lemko, three Southern Slavic — Bulgarian, Serbian and Croatian — as well as 10 non-Slavic, among others, Lithuanian, Greek, English, French and Portuguese. Additionally, it includes Japanese and three African languages: Swahili, Tamashek and Hausa. A look from afar at the Slavic and European house brings many benefits as it allows to avoid the European ethnocentrism. 
The authors worked in two ways: they presented the results of analyses of each data type separately (separate descriptions) or sought to integrate them in a synthetic form using the $\mathrm{CD}$ (holistic descriptions) ${ }^{31}$.

The methods of defining in national dictionaries the names for HOUSE/HOME such as Greek oikos, Lithuanian namai and namas, Polish and Russian dom, Belarussian chata, Lemko chyża, Czech di̊m and domov, Bulgarian kyšča, Serbian and Croatian kuća; French maison, Portuguese and Spanish casa, English home - subjected to analysis revealed differences, but also some commonalities.

In all 18 languages that we examined, the names for HOME/HOUSE are polysemous, but the definitions repeat two components: place and people. These two dimensions, spatial and human, are related in the sense that people usually live/dwell in a certain place (building). The notion of living/dwelling is crucial to the concept HOME/HOUSE. The conceptulisation of home as a dwelling place is primarily an event, not a location, because the function of home/house - living/dwelling — is the most important. The basic conceptual model of HOUSE/HOME can be reconstructed as a configuration of four facets ${ }^{32}$ forming an ordered whole (gestalt ${ }^{33}$ :

$$
\{[\text { SUBJECT }]+[\text { [EVENT }]+[\text { LOCATION] }+[\text { [FUNCTION }]\} \text {. }
$$

Somebody lives/dwells somewhere and satisfies there their needs. Subjects and locations may differ, functions are the same.

The following semantic components may be ascribed to the key predicate live/dwell - being the lexical representation of the facet [FUNCTION]:

1) 'to be somewhere for a longer period/ permanently';

2) 'at your own place, in a familiar place';

3) 'separated from the surroundings, in confinement;

4) 'in order to satisfy your needs' such as:

- sleep and rest,

- protection from cold,

- security,

- being with other people, including taking care of children (nurturing, bringing them up),

- usually also: satisfy hunger,

- usually also: 'personal hygiene (washing/ bathing; excreting),

- usually also: transfer of cultural models: speech, beliefs, norms and values,

- sometimes also: teaching a profession; earning a living.

The role of the [SUBJECT] living in a house/home is prototypically occupied by a family, in the case of the Polish concept HOUSE/HOME it is mother, in patriotic

31 S. Niebrzegowska-Bartmińska (2014) postulated favouring holistic descriptions.

${ }^{32}$ The term "facet" is taken from the dictionary of scientific information in the meaning of 'semantic subcategory', it is near-synonymous to "aspect", "dimension" and Langacker's "domain" (Langacker 2009:71-84), it is convenient due to its substantial flexibility and semantic capacity.

33 I use the term "Gestalt" in the same sense as cognitivists, cf. Lakoff, Johnson 1988: 96. 
profile — "Polish Mother". The identification of a house/home with a woman is most visible in African languages - in Swahili the word nyumba designates both the house and the wife.

The facet [LOCATION] is presented in detail and in many ways. The spatial, physical dimension of HOUSE, its appearance, structure, materials can be referred to using a rich vocabulary, quoted abundantly in the articles and properly classified there.

An important aspect of the concept HOME/HOUSE is ascribed to its axiology. In all languages the oppositions such as own/stranger, close/alien, inside/outside are clearly visible. HOUSE/HOME is on the side of what is familiar, close and refers to the interior, which gives it a highly positive evaluation. There is an opposition home vs. world.

In all studied languages the concept HOME/HOUSE is subject to metaphorisation. The first metaphoric extension involves the transfer of the name house/home to refer to the nearest surroundings, country and homeland, but also to the whole world (e.g. in the Bible). Secondly, we deal with semantic narrowing when house/home refers to the human body (also in the biblical tradition).

An important role for the CD play also cultural narratives about HOUSE/HOME, in particular the practice of building a house, moving to/from house/home, being at home / in the house, leaving, going out (or expelling) from home, returning HOME.

A deeper existential and personal but also social and cultural sense was attributed to house/home by Vaclav Havel, Czech writer and philosopher whose words could be used as the motto of our study:

For every man home (Czech: domov) is one of the main existential experiences. What a man considers his home (in the philosophical sense of the word) can be compared to a system of concentric circles in the centre of which is our own "self". My home is the place where I live at a certain time, the place that I'm used to and which - if I may say so - I enclosed in my own invisible envelope [...].

My home (domov) is this house (dum), where I live, the inhabited point or the city where I was born or currently live, my home (domov) for me is also my family, the world of my friends, the social and spiritual space in which I exist, my profession and place of work. My home (domov) is of course the country where I live, the language that I speak, the spiritual atmosphere of my country passed through the language spoken there. The Czech language, the specific Czech understanding of the world, the Czech historical experience, the Czech variants of heroism and cowardice, Czech humour - all these are inseparable components of my understanding of home (domov). [...]

Apart from that my home (domov) is also Europe and my feeling of being European, and our planet, its modern civilization, and even the whole world. But that's not all: my home (domov) for me is also my education, upbringing, habits, the environment in which I live and which I consider to be mine; if I belonged to any party, it definitely would also be for me my home (domov) (op. cit. Vanková 2012, p. 61).

\section{CONCLUDING REMARKS}

The programme EUROJOS is open. After the completion of the first stage of the programme in 2015 and preparation for the publication of the first 5 issues of LASiS (HOUSE/HOME, EUROPE, WORK, HONOUR, FREEDOM) the team of associates from 
14 countries declared their readiness to continue the programme. The preparation for the second stage labelled briefly Eurojos- 2 is in progress. Almost 80 cultural concepts have been shortlisted to be developed using the CD. Of those the largest number of indications have received among others the following: rodzina / family; zdrowie / zdorov'e / zdravi-nemoc / health; sprawiedliwość-niesprawiedliwość / spravedlivost' / justice-injustice; ojczyzna / rodina / domowina/otadżbina / homeland; demokracja / democracy; solidarność / solidarnost'/ solidarity; tolerancja-nietolerancja / tolerance; człowiek / man; dobro / good; miłość / ljubov' / love; wiara / faith; Bóg — Stwórca / God — Creator; mądrość / um / wisdom; odpowiedzialność / otvetstvennost' / responsibility; patriotyzm / patriotism; życie / żivot / zivot-smrt / life; chleb / bread; dobroć / goodness; naród / nation; piękno / beauty.

(C) Jerzy Bartmiński, 2018

\section{REFERENCES}

Ajdukiewicz, Kazimierz (1965). Logika pragmatyczna. Warszawa: PWN.

Anusiewicz, Janusz (1990). Językowo-kulturowy obraz kota w polszczyźnie. Etnolingwistyka 3: 95-141.

Anusiewicz, Janusz (1994). Lingwistyka kulturowa. Zarys problematyki. Wrocław: Wydawnictwo Uniwersytetu Wrocławskiego.

Apresjan, Jurij (1982/1974). Semantyka leksykalna. Synonimiczne środki języka. Transl. by Z. Kozłowska, A. Markowski. Wrocław: Zakład Narodowy im. Ossolińskich [Oryginał: Leksičeskaja semantika. Sinonimičeskie sredstva jazyka. 1974. Moskva: Nauka].

Bartmiński, Jerzy (1980). Założenia teoretyczne słownika. In SLSJ 1980: 7—36.

Bartmiński, Jerzy (1984). Definicja leksykograficzna a opis języka. In Słownictwo w opisie języka, ed. K. Polański, 9-21. Katowice: Uniwersytet Śląski.

Bartmiński, Jerzy (1988). Definicja kognitywna jako narzędzie opisu konotacji. In Konotacja, ed. J. Bartmiński, 169-170. Lublin: Wydawnictwo UMCS.

Bartmiński, Jerzy, Tokarski Ryszard (1993), Definicja semantyczna: czego i dla kogo? In O definicjach i definiowaniu, ed. J. Bartmiński, R. Tokarski, 47-61. Lublin: Wydawnictwo UMCS.

Bartmiński, Jerzy, Niebrzegowska, Stanisława (1994). Stereotyp słońca w polszczyźnie ludowej, Etnolingwistyka 6: 95-143.

Bartmiński, Jerzy, Niebrzegowska Stanisława (1998). Profile a podmiotowa interpretacja świata. In Profilowanie w języku $i$ w tekście. Ed. J. Bartmiński, R.Tokarski, 211-224. Lublin: Wydawnictwo UMCS.

Bartmiński, Jerzy, Niebrzegowska-Bartmińska, Stanisława (2008). Miejsce informacji kulturowej w znaczeniu słowa i w rekonstrukcji językowego obrazu świata. In Bunt tradycji - tradycja buntu, ed. G. Szwat-Gyłybow, M. Bogusławska, 65-77. Warszawa: Wydawnictwa UW.

Bartmiński, Jerzy, Prorok, Katarzyna (2012c). Złoto. In SSiSL T. I, cz. 4: 163-206.

Bartmiński, Jerzy (2013a). The cognitive definition as a text of culture. In The Linguistic Worldview. Ethnolinguistics, Cognition, and Culture, ed. by A. Głaz, D.S. Danaher, P. Łozowski, 161-180. London: Versita.

Bartmiński, Jerzy (2013b). Obraz mira v pol'skoj narodnoj tradicii. In Ètnolinguistica Slavica. K 90-letiju akademika Nikity Iljiča Tolstogo, 26-41. Moskva: Indrik. 
Bartmiński, Jerzy (2013c). Rola etymologii w rekonstrukcji językowego obrazu świata. LingVaria VIII, 2 (16): 233-245.

Bartmiński, Jerzy, Chlebda Wojciech (2013d). Problem konceptu bazowego i jego profilowania na przykładzie polskiego stereotypu Europy. Etnolingwistyka 25: 69-95.

Bartmiński, Jerzy (2014a). Narracyjny aspekt definicji kognitywnej. In Narracyjność języka i kultury, ed. D. Filar, D. Piekarczyk, 99-115. Lublin: Wydawnictwo UMCS.

Bartmiński, Jerzy (2014b). Ankieta jako pomocnicze narzędzie rekonstrukcji językowego obrazu świata. In Wartości w językowo-kulturowym obrazie świata Stowian i ich sąsiadów 3. Problemy eksplikowania i profilowania pojęć. Red. I. Bielińska-Gardziel, S. Niebrzegowska-Bartmińska, J. Szadura, 279-308. Lublin: Wydawnictwo UMCS.

Bartmiński, Jerzy (2015). Perspektywa semazjologiczna i onomazjologiczna w badaniach językowego obrazu świata, Poradnik Językowy, 1: 14-29.

Dokulil, Miloš (1979/ 1962). Teoria derywacji. Przełożyli z czeskiego A. Bluszcz i J. Stachowski. Wrocław: Ossolineum.

Fillmore, Charles (1971). Types of lexical information. In Semantics: An interdisciplinary reader in philosophy, linguistics and psychology. Ed. by D. D. Steinberg, L. A. Jako-bovits, pp. 370392. Cambridge: Univ. Press.

Głaz Adam, Danaher David, Łozowski Przemysław eds. (2013). The Linguistic Worldview: Ethnolinguistics, Cognition, and Culture. London: Versita.

Grech, Michał (2013). Obraz uniwersytetu w opinii mieszkańców Polski. Wrocław: Instytut Dziennikarstwa i Komunikacji Społecznej.

Grochowski, Maciej (1975). Środek czynności w strukturze zdania. Wrocław: Ossolineum.

Grochowski, Maciej (1993). Konwencje semantyczne a definiowanie wyrażeń językowych. Warszawa: Zakład Semiotyki Logicznej Uniwersytetu Warszawskiego.

Grzegorczykowa, Renata (1984). Zarys stowotwórstwa polskiego. Wyd. IV. Warszawa: Państwowe Wydawnictwo Naukowe.

Grzeszczak, Monika (2009). Definicja kognitywna pojęcia demokracji w języku polskim. Etnolingwistyka 21: 69-84.

Humboldt, Wilhelm von (2001/1836), Rozmaitość języków a rozwój umysłowy ludzkości. Przekład i wprowadzenie Elżbieta M. Kowalska. Lublin 2001: Redakcja Wydawnictw KUL [Oryginał: Über die Verschiedenheit des menschliches Sprachbaues und ihren Einfluss auf die geistige Entwicklung des Menschengeschlechts, 1836].

Ivanov, Vjačeslav, Toporov, Vladimir (1965). Slavjanskie jazykovye modelirujuščie semiotičeskie sistemy. Moskva: Nauka.

Jedliński, Ryszard (2000). Językowy obraz świata wartości w wypowiedziach uczniów kończących szkolę podstawową. Kraków: Wydawnictwo Naukowe Akademii Pedagogicznej.

Jodłowski, Stanisław (1971). Studia nad częściami mowy. Warszawa: Państwowe Wydawnictwo Naukowe.

Klemensiewicz, Zenon (1958). O znaczeniu stosunkowym struktur składniowych, Biuletyn Polskiego Towarzystwa Językoznawczego vol. XVII: $1-18$.

Lakoff, George, Johnson, Mark (1988/1980). Metafory w naszym życiu. Przełożył i wstępem opatrzył T.P. Krzeszowski. [Oryginał ang. Metaphors We Live By, 1980]. Warszawa: Państwowy Instytut Wydawniczy.

Langacker, Ronald W. (2009/2008). Gramatyka kognitywna. Wprowadzenie. [Tłum. zbiorowe z ang. Cognitive Grammar: A Basic Introduction 2008]. Kraków: Universitas. 
LASiS 2015-2017 - Leksykon aksjologiczny Stowian i ich sąiadów. Vol. 1, DOM, 2015, eds. J. Bartmiński, I. Bielińska-Gardziel, B. Żywicka, pp. 504. Vol. 2. Europa, 2018, ed. W. Chlebda, pp. 530. Vol. 3, PRACA, 2016, eds. J. Bartmiński, M. Brzozowska, S. NiebrzegowskaBartmińska, pp. 455. Vol. 5, HONOR, 2017, eds. Petar Sotirov, Dejan Ajdačić, pp. 431. Lublin: Wydawnictwo UMCS.

Lippmann, Walter (1922). Public opinion. New York: The Macmillan Company.

Łuczyński, Michał (2008). Kognitywna definicja Marzanny — próba rekonstrukcji fragmentu mitologicznego obrazu świata Słowian. Studia Mythologica Slavica XI: 173-196.

Łuczyński, Michał (2011). Kognitywna definicja Peruna: etnolingwistyczna próba rekonstrukcji fragmentu tradycyjnego mitologicznego obrazu świata. Studia Mythologica Slavica XIV: $217-228$.

Łuczyński, Michał (2012). Kognitywna definicja Welesa Wołosa: Etnolingwistyczna próba rekonstrukcji fragmentu słowiańskiego tradycyjnego mitologicznego obrazu świata. Studia Mythologica Slavica XV: 169-178.

Maksymiuk-Pacek, Beata, Niebrzegowska-Bartmińska, Stanisława eds. (2009). Bibliografia adnotowana lubelskiego zespolu etnolingwistycznego (do roku 2009). Lublin: Wydawnictwo Polihymnia.

Malinowski, Bronisław (1987/1935), Ogrody koralowe i ich magia. Język magii i ogrodnictwa. Dzieła t. 5. Przełożyła B. Leś. Warszawa 1987: Państwowe Wydawnictwo Naukowe.

Nepop-Ajdaczyć, Lidia (2007). Polska etnolingwistyka kognitywna. Kijów: Wydawnictwo Uniwersytetu Kijowskiego.

Niebrzegowska, Stanisława (1990). Gwiazdy w ludowym językowym obrazie świata. In Językowy obraz świata, ed. J. Bartmiński, 147-166. Lublin: Wydawnictwo UMCS.

Niebrzegowska-Bartmińska Stanisława (2014). Od separacyjnego do holistycznego opisu językowego obrazu świata. Na marginesie dyskusji nad kształtem artykułów w "Leksykonie aksjologicznym Słowian i ich sąsiadów". In Wartości w językowo-kulturowym obrazie świata Stowian i ich sasiadów. 3. Problemy eksplikowania i profilowania pojęć. Eds. I. Bielińska-Gardziel, S. Niebrzegowska-Bartmińska, J. Szadura, 71-102. Lublin: Wydawnictwo UMCS.

Pawlas, Szymon (2013). Obraz Boga/bogów w wybranych językach ugrofińskich (węgierskim, fińskim, estońskim i udmurckim). [Manuscript od doctoral dissertation, UW].

Pawłowski, Tadeusz (1978). Rodziny znaczeń i ich definiowanie. Studia Filozoficzne, 2, 81—99.

Putnam Hilary, 1975, Mind, Language and Reality. Philosophical Papers, vol. 2. Cambridge: Cambridge Univeristy Press.

Przybylska, Renata (2003), Wstęp do nauki o języku polskim [An introduction to the Polish language]. Handbook for universities. Kraków: Wydawnictwo Literackie.

SJP Dor — Doroszewski, Witold ed. (1958-1969), Stownik języka polskiego, vol. 1-11. Warszawa: Państwowe Wydawnictwo Naukowe.

Skowronek, Bogusław (2010). Definicja kognitywna terminów „tabloid” i „tabloidyzacja”. Oblicza Komunikacji 3: 24-36.

SLSJ — Bartmiński, Jerzy ed. (1980). Stownik ludowych stereotypów językowych. Zeszyt próbny [Dictionary of folk linguistic stereotypes. Pilot issue]. Wrocław: Wydawnictwo Uniwersytetu Wrocławskiego.

Smyk, Katarzyna (2009). Choinka w kulturze polskiej. Symbolika drzewka i ozdób. Kraków: Univeritas.

SSiSL - Stownik stereotypów i symboli ludowych [Dictionary of Folk Stereotypes and Symbols]. Koncepcja całości i red. J. Bartmiński, zast. red. S. Niebrzegowska (Bartmińska). T. I. Kosmos, cz. 1—4, 1996-2012. T. II, Rośliny, cz. 1, Zboża, 2017. Lublin: Wydawnictwo UMCS. 
Tolstye, Svetlana Mihajlovna i Nikita Iljič (1984). Princypy sostavlenija etnolingvističeskogo slovara slavjanskich drevnostej. In Etnolingvističeskij slovar' slavjanskich drevnostej. Proekt slovnika. Predvaritelnye materialy, 6-22. Moskwa.

USJP (2003). Uniwersalny stownik języka polskiego, ed. S. Dubisz. Warszawa: Wyd. Naukowe PWN.

Wierzbicka, Anna (1971). Kocha, lubi, szanuje. Medytacje semantyczne. Warszawa: Wiedza Powszechna.

Wierzbicka, Anna (1984). Apples are not 'kind of fruit'. The semantics of human categorization. American Ethnologist 11 (2): 313-328.

Wierzbicka, Anna (1985). Lexicography and Conceptual Analysis. Ann Arbor: Karoma Publishers.

Wierzbicka, Anna (1991). Uniwersalne pojęcia ludzkie i ich konfiguracje w różnych kulturach. Etnolingwistyka 4: 7 - 40.

Wierzbicka, Anna (1993). Nazwy zwierząt. In J. Bartmiński, R. Tokarski eds. O definicjach i definiowaniu, 251-267. Lublin: Wydawnictwo UMCS.

Wierzbicka, Anna (1996). Między modlitwą a przekleństwem: ”O Jezu!” i podobne wyrażenia na tle porównawczym. Etnolingwistyka 8: 25-39.

Wierzbicka, Anna (1999). Semantyka i Ewangelia: Odczytując na nowo przypowieść o faryzeuszu i celniku. In $W$ zwierciadle języka i kultury, ed. J. Adamowski, S. Niebrzegowska, 47-58. Lublin: Wydawnictwo UMCS.

Wierzbicka, Anna (2004). Jak można mówić o Trójcy świętej w słowach prostych i uniwersalnych. Lublin: Wydawnictwo UMCS.

Wierzbicka, Anna (2006a). Semantyka. Jednostki elementarne i uniwersalne. Lublin: Wydawnictwo UMCS [Tłum. książki Semantics. Primes and Univerals, 1996].

Wierzbicka, Anna (2006b). Współczesne dylematy moralne przez pryzmat dwóch języków angielskiego i polskiego. Etnolingwistyka 18: 145-164.

Wierzbicka, Anna (2008). Podmiot rozdwojony w sobie: dwa języki, dwie kultury, jedno (?) ja. In Podmiot w języku i kulturze, ed. J.Bartmiński, A. Pajdzińska, 139-159. Lublin: Wydawnictwo UMCS.

Wierzbicka, Anna (2011). Polskie słowa-wartości w perspektywie porównawczej. Część I. Dobroć. Etnolingwistyka 23: 45-66.

Wierzbicka, Anna (2012). Polskie slowa-wartości w perspektywie porównawczej. Część II. Prawość i odwaga. Etnolingwistyka 24: 19-46.

Wierzbicka, Anna (2013). Polish zwierzęta 'Animals' and jabłka 'Apples'; an Ethnosemantic Inquiry. In The Linguistic Worldview: Ethnolinguistics, Cognition, and Culture, eds. A. Głaz, D. Danaher, P. Łozowski, 137-159. London: Versita.

Wójtowicz, Magdalena (2013). Definicja kognitywna jako sposób opisu semantyki symbolu na przykładzie liczby siedem, Roczniki Kulturoznawcze KUL, 4: 71-87.

Zinken, Jörg (2009). The Ethnolinguistics School of Lublin and Anglo-American Cognitive Linguistics, [in:] Jerzy Bartmiński, Aspects of Cognitive Ethnolinguistics, London, $1-5$.

Żmigrodzki, Piotr (2010), "Definicja leksykograficzna a opis języka" — ćwierć wieku później. Jeszcze o roli naiwnego obrazu świata w definiowaniu. In Etnolingwistyka a leksykografia. Ed. W. Chlebda, 33 - 40. Opole: Wydawnictwo Uniwersytetu Opolskiego.

\section{Article history:}

Received: 20 July 2018

Revised: 15 September 2018

Accepted: 21 September 2018

\section{История статьи:}

Дата поступления в редакцию: 20 июля 2018

Дата принятия к печати: 21 сентября 2018 


\section{For citation:}

Bartmiński, Jerzy (2018). In the circle of inspiration of Anna Wierzbicka: The cognitive definition 30 years later. Russian Journal of Linguistics, 22 (4), 749-769. doi: 10.22363/2312-9182-2018-22-4749-769.

\section{Для цитирования:}

Bartmiński, Jerzy. In the circle of inspiration of Anna Wierzbicka: The cognitive definition -30 years later // Вестник Российского университета дружбы народов. Серия: Лингвистика = Russian Journal of Linguistics. 2018. T. 22. № 4. C. 749-769. doi: 10.22363/2312-9182-2018-22-4-749-769.

\section{Bionote:}

JERZY BARTMIŃSKI is Professor Emeritus at Maria Curie-Skłodowska University and the Institute of Slavic Studies of the Polish Academy of Sciences. Active member of the Polish Academy of Arts and Sciences. His research interests embrace: semantyka leksykalna, aksjologia lingwistyczna, tekstologia, folklorystyka, etnolingwistyka. He is the author of books O jezzyku folklore [O jazyke fol'klora], Wrocław 1973; Jazykovoj obraz mira: očerki po etnolingvistike, Moskwa 2005; Językowe podstawy obrazu świata [Jazykovye osnovy kartiny mira], Lublin 2006; Stereotypy mieszkaja w języku [Stereotipy żivut v jazyke] . Lublin 2007; Aspects of Cognitive Ethnolinguistics, London 2009; Tekstologia Warszawa 2009 (co-author: Stanisława Niebrzegowska-Bartmińska); Polskie wartości $w$ europejskiej aksjosferze [Pol'skie cennosti v evropejskoj aksiosfere] Lublin 2014. Editor of the volume Wspótczesny język polski [Sovremennyj pol'skij jazyk] (Wrocław 1993), founder and editor of the journal "Ethnolinguistics" vol. 1-30; editor of Stownik stereotypów i symboli ludowych [Slovar' narodnyh stereotipov i simvolov] (1996-), initiator and editor of Leksykon aksjologiczny Stowian i ich sąsiadów [Aksiologičeskij leksikon slavjan i ih sosedov] (Lublin 2015-). Decorated with the Medal of the President of the Republic of Poland Person of Merit for the Polish Language.

Contact information: jerzy.bartminski@poczta.umcs.lublin.pl

\section{Сведения об авторе:}

ЕЖИ БАРТМИНСКИ - заслуженный профессор Университета Марии Склодовской-Кюри и Института славяноведения Польской академии наук, действительный член Польской академии искусств и наук. Его научные интересы включают лексическую семантику, лингвистическую аксиологию, текстологию, фольклористку, этнолингвистику. Он является автором книг O języku folkloru [О языке фольклора], Wrocław 1973; Языковой образ мира: очерки по этнолингвистике, Москва 2005; Językowe podstawy obrazu świata [Языковые основы картины мира], Lublin 2006; Stereotypy mieszkaja w języku [Стереотипы живут в языке], Люблин, 2007; Aspects of Cognitive Ethnolinguistics [Аспекты когнитивной этнолингвистики], Лондон, 2009; Tekstologia [Текстология] Warszawa 2009 (в соавторстве со Станиславой Небржеговской-Бартминской); Польские иенности в европеейской аксиосфере, Люблин 2014. Главный редактор тома «Современный польский язык» (Вроцлав 1993), основатель и редактор журнала «Этнолингвистика» том $1-30$; редактор Словаря народных стереотипов и символов (1996-), основатель и редактор Аксиологического лексикона славян и их соседей (Люблин, 2015). Награжден медалью Президента Республики Польша за заслуги в области польского языка.

Контактная информация: jerzy.bartminski@poczta.umcs.lublin.pl 